Vol. 3 No. 1 February 2019

ISSN 2580-5029

\title{
IDENTIFICATION OF 1-AMINOCYCLOPROPANE-1-CARBOXYLIC ACID (ACC)-DEAMINASE PRODUCING ENDOPHYTIC BACTERIA FROM LOCAL AGRICULTURAL PLANTATION BASED ON 16S RIBOSOMAL RNA GENE AS GENETIC MARKER
}

\author{
Rumella Simarmata1 ${ }^{*}$, Ngadiman ${ }^{1}$, Muhammad Saifur Rohman², Partomuan Simanjuntak ${ }^{3}$ \\ 1Universitas Gadjah Mada, Yogyakarta, Indonesia \\ ${ }^{2}$ Research Center of Biotechnology, Indonesian Institute of Science, Cibinong, Indonesia \\ 3Universitas Pancasila, Jakarta, Indonesia \\ *rumella_2001@yahoo.com
}

\begin{abstract}
The objective of this work was to isolate and identify of 1-aminocyclopropane-1-carboxylic acid (ACC) deaminase producing endophytic bacteria from root of local agricultural plantation by using $16 S$ rRNA gene as genetic marker. Twelve root samples were collected from local agricultural plantation in Java area. After surface sterilization, each root sample was inoculated in nutrient agar media and the grown colonies were further purified and tested for the ability to grow in $N$-free minimal medium containing AIB as a sole of nitrogen source. The selected colonies were further tested for their ACC deaminase activity by measuring the rate of conversion of ACC into $\alpha$-ketobutyrate. From this work, 12 bacterial strains that exhibited the ACC deaminase activity by 123.75 to $1461.44 \mathrm{nmol} \alpha$-ketobutyrate/mg/hour were successfully isolated. Based on the 16SrRNA gene sequences, those bacterial isolates were identified as Sphingobacterium multivorum BK1, Bacillus mycoides CB2, Pantoea dispersa CK4, Pantoea agglomerans KD6.2, Enterobacter ludwigii KW3, Bacillus aryabhattai TW7, Pseudomonas monteilii KS12, Pseudomonas plecoglossicida KS16.2, Pseudomonas putida PIR3C, Stenotrophomonas maltophilia PIR5, Lysinibacillus pakistanensis PIC5, and Raoultella terrigena PCM8. Pseudomonas putida PIR3C and Pseudomonas monteilii KS12 showed promising ACC deaminase activity and therefore it could be as a good candidate for further application in plant growth promoting in stress conditions.
\end{abstract}

Keywords: endophytic bacteria, ACC deaminase, $16 S$ rRNA gene, $\alpha$-ketobutyrate

\section{INTRODUCTION}

Plant experiences with the biotic and abiotic stress conditions. Such biotic and abiotic stress conditions elicit ethylene synthesis in plants, albeit ethylene itself is important for normal plant growth and produced in very low level of concentration $(<0.05 \mu \mathrm{l} / \mathrm{l})$. During senescence and fruit ripening, ethylene production increases up to $\sim 100 \mu \mathrm{l} / \mathrm{l}$ and therefore, ethylene is also important for plant physiological regulator (Bleecker and Kende, 2000; Glick, 2005). Plant ethylene synthesis in the response of 
biotic or abiotic stress is usually far greater than normal conditions. Ethylene is synthesized from an intermediate compound, which is known as 1aminocyclopropane-1-carboxylate (ACC), from S-adenosylation of methionine in order to give S-adenosylmethionine, which is oxidatively cleaved to give ethylene (Yao et al, 2000). Therefore, reducing the ACC accumulation inhibits ethylene synthesis in higher plant. ACC deaminase is an enzyme that specifically breaks the cyclic ring of ACC to produce $\alpha$ ketobutyrate and ammonium (Honma and Shimomura, 1978; Yao et al., 2000). Introducing of ACC deaminase encoding gene in higher plant reduce level of ethylene and delays the ripening progression of fruit (Klee et al., 1991).

Endophytic bacteria has important role for plant growth promotion and usually they are harbored inside of healthy plant but do not lead pathogenic reaction (Ding and Melcher, 2016; Ryan et al., 2008). It is likely that endophytic bacteria are indispensable integrative part of the plant systems. Endophytic bacteria may help the plants to activate the immune system that protects the plants from the harsh environmental conditions such as cold, salinity, drought stress, nutrition limitation, pathogenic attacking, detoxification, etc.
(Kozyrovska, 2013). Although the clear mechanism on how the endophytic bacteria support plant growth promotion remains elusive, producing of ACC deaminase from endophytic bacteria is believed to be one mechanism of the plant growth promotion. Several bacteria either endophytic or non endophytic containing ACC encoding gene have been isolated and well characterized (Honma and Shimomura, 1978; Glick, 2005; Glick, 2014). Successful stories on the field application of bacteria harboring ACC deaminase encoding gene to ameliorate the plant growth under stress conditions have also been reported previously (Belimov et al. 2001; Grichko and Glick, 2001; Mayak et al. 2004; Reed and Glick, 2005). Therefore, it is important to discover more endophytic bacteria producing ACC deaminase. The objective of this work was to isolate and identify the ACC deaminase producing endophytic bacteria from the plants and crops of local agricultural plantation in Java area.

\section{METHODS}

Isolation of endophytic ACC deaminase producing bacteria

Twelve root samples of tea (Camellia sinensis), cocoa (Theobroma cacao), paddy (Oryza sativa var. IR4; $O$. sativa var. Ciherang; O. sativa L. var. 
Gemar), onion (Allium cepa), chili (Capsicum annum; C. chinense) and potato (Solanum sp. tuberosum) were obtained and collected from the area of Gunung Kidul, Bantul, Kulon Progo, and Wonosobo. Samples were collected during the dry season periods (October, 2014). In order to selectively isolated root endophytic bacteria, the root samples were subjected for surface sterilization and then were placed onto nutrient agar madia. Surface sterilization of the root samples were as follows, the root samples were washed in running water and followed by the immersion sequence in $75 \%$ ethanol for $1 \mathrm{~min}, 20 \%$ $\mathrm{NaClO}$ for $3 \mathrm{~min}$ and $75 \%$ ethanol for 0.5 min (Fisher and Petrini, 1992; Hallmann et al., 1997). The inoculated agar media were incubated at room temperature for 24 hours. The growth colonies were further purified to obtained pure single colonies. The selected colonies were further tested for the ACC deaminase production and activity.

\section{Selection of ACC deaminase producing endophytic bacteria}

In order to test the ability of selected bacterial isolate to produce ACC deaminase, the qualitative test were carried out. Each colony was grown in the minimal DF salt, either supplemented with or without nitrogen sources. The DF salt media had the following compositions (per liter) of $4.0 \mathrm{~g} \mathrm{KH}_{2} \mathrm{PO}_{4}$, $6.0 \mathrm{~g} \mathrm{Na}_{2} \mathrm{HPO}_{4}, 0.2 \mathrm{~g} \mathrm{MgSO}_{4} 7 \mathrm{H}_{2} \mathrm{O}, 2.0 \mathrm{~g}$ glucose, $2.0 \mathrm{~g}$ gluconic acid and $2.0 \mathrm{~g}$ citric acid with trace elements: $1 \mathrm{mg}$ $\mathrm{FeSO}_{4} .7 \mathrm{H}_{2} \mathrm{O}, 10 \mathrm{mg} \mathrm{H}_{3} \mathrm{BO}_{3}, 11.19 \mathrm{mg}$ $\mathrm{MnSO}_{4} \mathrm{H}_{2} \mathrm{O}, 124.6 \mathrm{mg} \mathrm{ZnSO}_{4} .7 \mathrm{H}_{2} \mathrm{O}, 78.22$ $\mathrm{mg} \mathrm{CuSO}_{4} .5 \mathrm{H}_{2} \mathrm{O}, 10 \mathrm{mg} \mathrm{MoO}_{3}, \mathrm{pH} 7.2$ (Dworkin and Foster, 1958). After sterilization DF salt media were supplemented with different nitrogen sources. The sterilized DF salt mediums were then added $3 \mathrm{mM}$ of amino isobutyric acid (AIB) as nitrogen source (Penrose and Glick, 2003). For the negative control, the sterilized DF salt medium without any nitrogen source was prepared. The grown colonies were selected and used for further analysis of ACC deaminase enzyme activity.

\section{The cell free extract ACC deaminase activity assay}

The cell free extract of ACC deaminase activity was determined by measuring the amount of $\alpha$-ketobutyrate released from enzymatic breakdown of ACC. The bacteria were grown and enriched in TSB medium for 48 hours at room temperature. The cell pellets were harvested by centrifugation at $3000 \mathrm{rpm}$ for 30 minutes at $4^{\circ} \mathrm{C}$. The cell pellets 
were then suspended in $5 \mathrm{ml}$ of DF salts medium and centrifuged. Supernatants were discarded and then pellets were suspended in $5 \mathrm{ml}$ DF salts media containing AIB as nitrogen source for 20 hours at room temperature. The cell pellets were harvested by centrifugation at $3000 \mathrm{rpm}$ for 30 minutes at $4^{\circ} \mathrm{C}$. The cell pellets were then suspended in $5 \mathrm{ml}$ of $0.1 \mathrm{M}$ phosphate buffer $\mathrm{pH} 7.00$ and centrifuged. Supernatants were discarded and then pellets were suspended in 600 $\mu \mathrm{l}$ of $0.1 \mathrm{M}$ phosphate buffer $\mathrm{pH}$ 8.00. Cell pellets were then disrupted by sonication method $3 \times 30$ seconds and centrifuged at $13000 \mathrm{rpm}$ for 10 minutes at $4^{\circ} \mathrm{C}$ (Penrose and Glick, 2003). The cell free extracts were collected and used as ACC deaminase crude extract enzyme for further enzymatic assay (Honma and Shimomura, 1978). The mixture containing $200 \mu \mathrm{l}$ of cell free extract supernatant and $20 \mu \mathrm{L} 0.5 \mathrm{M}$ of ACC substrate were homogenized and incubated at $30{ }^{\circ} \mathrm{C}$ for $15 \mathrm{~min}$. Thereafter,

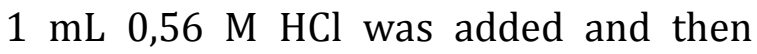
centrifuged at $16000 \times \mathrm{g}$ for $5 \mathrm{~min} .1 \mathrm{~mL}$ supernatant was added with $800 \mu \mathrm{L} 0,56$ $\mathrm{M} \mathrm{HCl}$ and $300 \mu \mathrm{L}$ dinitrophenyl hydrizyl $(0.2 \%$ in $2 \mathrm{M} \mathrm{HCl})$. The samples were homogenized with vortex and incubated at $30{ }^{\circ} \mathrm{C}$ for $30 \mathrm{~min}$ and then added $2 \mathrm{~mL}$ $2 \mathrm{~N} \mathrm{NaOH}$. The color change that is formed shows the reaction of dinitrophenyl hydrizyl with $\alpha$-ketobutirate formed. Colorimetric analysis was performed with a spectrophotometer at $540 \mathrm{~nm}$ wavelength.

The total protein in supernatant of cell free extract were determined by the Biorrad Assay method with used the bovine serum albumin (BSA) as standard. A total of $2 \mu \mathrm{L}$ crude enzymes, $200 \mu \mathrm{L}$ Biorrad solution and 798 aquades were homogenized and measured at absorbance $595 \mathrm{~nm}$. The standard protein is used by measuring the absorbance of various concentrations of BSA (Bovine Serum Albumin) (Bradford, 1976).

The ACC deaminase was expressed as the amount of $\alpha$-ketobutirate (nmol) produced per mg protein per hour.

\section{Identification of endophytic ACC deaminase producing bacteria}

Bacterial isolate identification was carried out by observation phenotypic appearance and also based on the sequence of 16SrRNA gene. Phenotypic appearances were determined according to the Bergeys Manual Determinative Bacteriology. In order to amplify the 16SrRNA gene, the genomic DNA from selected bacteria was used as template for PCR amplification with the following universal primers, 27F (5' AGA GTT TGA 
TCC TGG CTC AG - 3') and 1492 R (5'- GTT

TAC CTT GTT ACG ACT T- 3'). The PCR method was carried out using GoTaq Green PCR kit and the PCR products were then directly sequenced. The complete sequencing results were built by using DNA Baser suite and used for further nucleotide BLAST analysis (https://blast.ncbi.nlm.nih.gov/).

Phylogenetic tree was constructed by using MEGA 7 software (Kumar et al., 2016).

\section{RESULTS AND DISCUSSION}

Isolation and selection of ACC deaminase producing endophytic bacteria

Based on the morphological colonies and cells appearance, we have successfully isolated 120 bacterial strains from root of local agricultural plants and crops. The isolated bacterial strains were further tested for their ability to grow on minimal media DF salt agar containing AIB as sole of nitrogen sources. Among the 120 bacterial strains only 12 bacterial strains, which showed the positive response when grown on DF salt media containing $\mathrm{AIB}$ as a sole of nitrogen source (data not shown). Although most of the selected bacterial strains exhibited poor growth on DF salt agar media, it is worth to check the ACC deaminase production those bacterial strains. The ACC deaminase production was induced by ACC substrate and the ACC deamainase activity was determined by measuring the amount of $\alpha$-ketobutyrate released from the breakdown of ACC molecule. Among the 12 bacterial strains, only PIR 3C and KS 12 showed the significant ACC deaminase activity by the means of $\alpha$-ketobutyrate production (Figure 1). The PIR 3C and KS 12 were able to convert ACC into $\alpha$-ketobutyrate by the rate of 1461.44 and $1290.29 \mathrm{nmol}$ $\alpha$-ketobutyrate $/ \mathrm{mg} / \mathrm{h}$, respectively. The other 11 bacterial strains were only able to produce the ACC deaminase with the rate of less than 702.11 nmol $\alpha$ ketobutyrate $/ \mathrm{mg} / \mathrm{h}$. Therefore among the 12 bacterial strains, only two bacterial strains that exhibited ACC deaminase activity might be a good candidate for further exploration on ACC deaminase producing endophytic bacterium. 


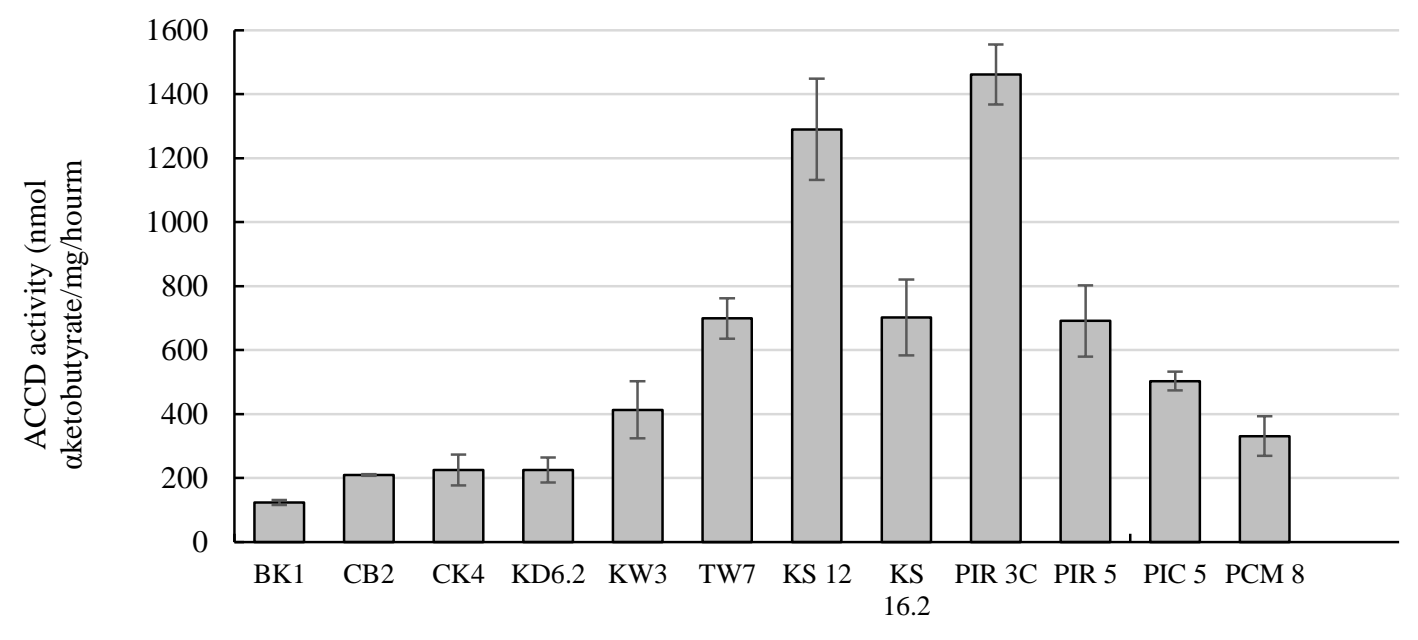

Bacterial Strains

Figure 1. The activity of ACC deaminase extracted from bacterial strains. ACC deaminase activity was measured by calculating the amount of a $\alpha$-ketobutyrate released in the reaction mixture.

Phenotypic appearances and molecular identification of ACC deaminase producing endophytic bacteria

Twelve selected bacterial strains showing the ACC deaminase activity isolated from the root of plants or crops of local agricultural plantations were further characterized by morphological and molecular level. Generally it can be said that there was strong correlation between the morphological (Table 1) and molecular characterization.

Table 1. Phenotypic characterization of bacterial strains based on their cell morphology and gram staining. The cell morphology was examined microscopically with $1000 \mathrm{x}$ magnification. The Gram character was determined by gram staining method.

\begin{tabular}{lllll}
\hline No & Bacterial Strains & Gram Staining & Colony Shape & Cell Shape \\
\hline 1 & BK 1 & Negative & Round & Rod \\
2 & CB 2 & Positive & Filamentous & Rod \\
3 & CK 4 & Negative & Round & Rod \\
4 & KD 6.2 & Negative & Round & Rod \\
5 & KW 3 & Negative & Round & Rod \\
6 & TW 7 & Positive & Circulair & Rod \\
7 & KS 12 & Negative & Circulair & Rod \\
8 & KS 16 & Negative & Circulair & Rod \\
9 & PIR 3C & Negative & Circulair & Rod \\
10 & PIR 5 & Negative & Circulair & Rod \\
11 & PIC 5 & Positive & Circulair & Rod \\
12 & PCM 8 & Negative & Circulair & Rod \\
\hline
\end{tabular}


Biotropic 2019. Vol.3(1): 13 - 23

Identification of 1-Aminocyclopropane-1-Carboxylic Acid (ACC)-Deaminase Producing Endophytic Bacteria from Local Agricultural Plantation Based on 16s Ribosomal RNA Gene As Genetic Marker

From the molecular Firmicutes and the remaining strains characterization, we could identify belonged to the Bacteriodetes. Further bacterial strain individually up to genus breakdown of the proteobacteria group level. The constructed phylogenetic tree indicated that most of the member belong (Figure 2) showed that among the 12 to the proteobacteria included bacterial strains could be classified into Pseudomonas,

Enterobacter, three main different phylum, i.e. Stenotrophomonas, Pantoea, and Proteobacteria, Firmicutes, and Raoultella. Firmicutes were dominated by Bacteriodetes. Among the 12 bacterial Bacillus, while the Spingobacterium the strains, 8 strains belonged to only Bacteriodetes member was found. Proteobacteria, 3 strains belonged to

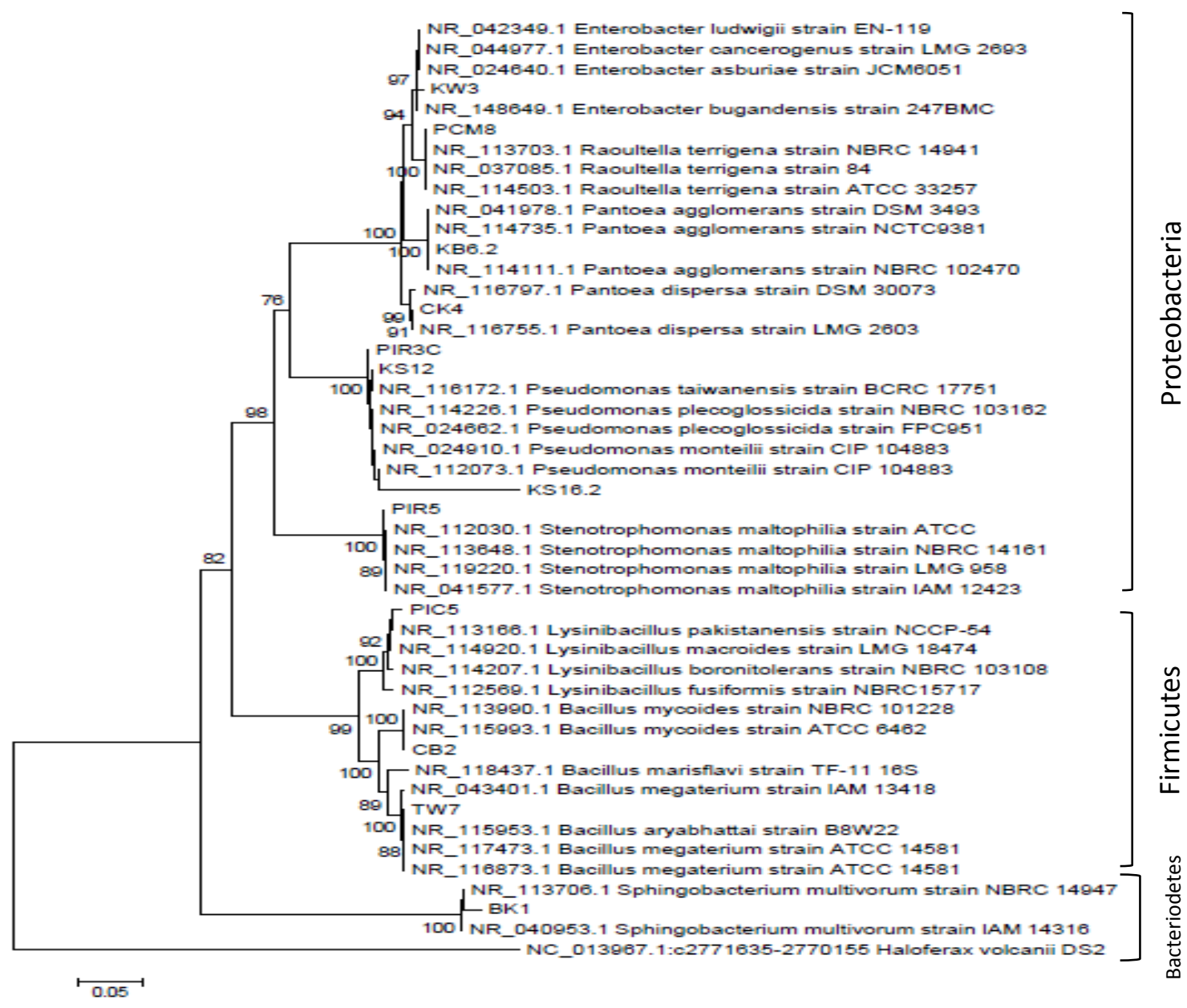

Figure 2. The evolutionary history of bacterial strains was inferred using the NeighborJoining method. The percentage of replicate trees in which the associated taxa clustered together in the bootstrap test (500 replicates) are shown next to the branches. The tree is drawn to scale, with branch lengths in the same units as those of the evolutionary distances used to infer the phylogenetic tree. The evolutionary distances were 
computed using the Kimura 2-parameter method and are in the units of the number of base substitutions per site. The rate variation among sites was modeled with a gamma distribution (shape parameter $=1$ ). Evolutionary analyses were conducted in MEGA7.

Among the 12 bacterial strains proteobateria dominated the isolated bacterial strains. The dominance of proteobacteria was also found to be the common phenomenon in endophytic bacteria (Moore et al., 2006; Taghavi et al., 2009). Interestingly, one member of proteobacteria, PIR5, which was identified to be Stenotrophomonas maltophila, was considered as the multidrug resistance strain.

If we considered to the ACC deaminase activity, Stenotrophomonas maltophila PIR5 was not considered as potential ACC deaminase producer, when the $\alpha$-ketobutyrate production was used as ACC deaminase activity marker. The PIR 3C, which was identified as Pseudomonas putida, and we called hereafter as Pseudomonas putida PIR 3C, exhibited the highest ACC deaminase activity among the member of proteobacteria group. So far the well known of ACC deaminase producing bacteria is from the group of Pseudomonas. In this work the member of Pseudomonas group, exhibit higher ACC deaminase activity significantly. Pseudomonas monteilii KS 12, which a member of proteobacteria group, was also produce high ACC deaminase activity compared to the other isolates.

From the member of Firmicutes which consist of Lysinbacillus pakistanensis PIC5, Bacillus mycoides CB2, Bacillus aryabhatai TW7, and Bacillus marisflavi PIC11, were also produce significantly lower ACC deaminase activity compared to the Pseudomonas putida PIR 3C. Similarly, the Spingobacterium multivorum BK1, which was the only member of Bacteriodetes, also showed the lower ACC deaminase activity. Therefore among the 12 bacterial strains the Pseudomonas putida PIR 3C and Pseudomonas monteilii KS 12 were the most promising candidate for ACC deaminase producing bacterium. It is necessary then to check whether Pseudomonas putida PIR 3C and Pseudomonas monteilii KS 12 are able to support the plant growth in the stress condition by examining the ACC reduction.

\section{CONCLUSION}

From this work we have successfully isolate and identified 12 ACC deaminase producing bacterial strains. Among them, Pseudomonas putida PIR 3C 
and Pseudomonas monteilii KS 12 showed promising ACC deaminase activity and therefore it could be as a good candidate for further application in plant growth promoting in stress conditions.

\section{ACKNOWLEDGEMENT}

This work was partially funded by the Higher Education of Priority Research Contract

No. 015 / SP2H / LT / DRPM /II/2016.

\section{REFERENCES}

Belimov, A. A., Safronova, V. I., Sergeyeva, T. A., Egorova, T. N., Matveyeva, V. A., Tsyganov, V. E., Borisov, A. Y., Tikhonovich, I. A., Kluge, C., Preisfeld, A., Dietz, K. J., \& Stepanok, V. V. (2001). Characterization of plant growth promoting rhizobacteria isolated from polluted soils and containing 1aminocyclopropane-1-carboxylate deaminase. Canadian Journal of Microbiology, 47(7), 642-652.

Bleecker, A. B., \& Kende, H. (2000). Ethylene: a gaseous signal molecule in plants. Annual review of cell and developmental biology, 16(1), 1-18. https://doi.org/10.1146/annurev.ce $\underline{\text { llbio.16.1.1 }}$

Bradford, M. M. (1976). A rapid and sensitive method for the quantitation of microgram quantities of protein utilizing the principle of protein-dye binding. Analytical biochemistry, 72(1-2), 248-254.

Ding, T., \& Melcher, U. (2016). Influences of plant species, season and location on leaf endophytic bacterial communities of non-cultivated plants. PloS one, 11(3), e0150895. https://doi.org/10.1371/journal.po $\underline{\text { ne.0150895 }}$

Dworkin, M., \& Foster, J. W. (1958). Experiments with some microorganisms which utilize ethane and hydrogen. Journal of bacteriology, 75(5), 592-601

Fisher, P. J., \& Petrini, O. (1992). Fungal saprobes and pathogens as endophytes of rice (Oryza sativa L.). New Phytologist, 120(1), 137-143. https://doi.org/10.1111/j.14698137.1992.tb01066.x

Glick, B. R. (2005). Modulation of plant ethylene levels by the bacterial enzyme ACC deaminase. FEMS microbiology letters, 251(1), 1-7. https://doi.org/10.1016/j.femsle.20 05.07.030

Glick, B. R. (2014). Bacteria with ACC deaminase can promote plant growth and help to feed the world. Microbiological research, 169(1), 3039.

https://doi.org/10.1016/i.micres.20 $\underline{13.09 .009}$

Grichko, V. P., \& Glick, B. R. (2001). Amelioration of flooding stress by ACC deaminase-containingplant growth-promoting bacteria. Plant Physiology and Biochemistry, 39(1), 11-17.

https://doi.org/10.1139/cjm-46$\underline{12-1159}$

Hallmann, J., Quadt-Hallmann, A., Mahaffee, W. F., \& Kloepper, J. W. (1997). Bacterial endophytes in agricultural crops. Canadian Journal of Microbiology, 43(10), 895-914. https://doi.org/10.1139/m97-131 
Honma, M., \& Shimomura, T. (1978). Metabolism of 1aminocyclopropane-1-carboxylic acid. Agricultural and Biological Chemistry, 42(10), 1825-1831. https://doi.org/10.1080/00021369. $\underline{1978.10863261}$

Klee, H. J., Hayford, M. B., Kretzmer, K. A., Barry, G. F., \& Kishore, G. M. (1991). Control of ethylene synthesis by expression of a bacterial enzyme in transgenic tomato plants. The Plant Cell, 3(11), 1187-1193. https://doi.org/10.1105/tpc.3.11.11 $\underline{87}$

Kozyrovska, N. O. (2013). Crosstalk between endophytes and a plant host within information-processing networks. Biopolymers and cell, (29, no.3), 234-243. http://dx.doi.org/10.7124/bc.0008 $\underline{1 \mathrm{D}}$

Kumar, S., Stecher, G., \& Tamura, K. (2016). MEGA7: molecular evolutionary genetics analysis version 7.0 for bigger datasets. Molecular biology and evolution, 33(7), 1870-1874. https://doi.org/10.1093/molbev/m $\underline{\text { sw054 }}$

Mayak, S., Tirosh, T., \& Glick, B. R. (2004). Plant growth-promoting bacteria that confer resistance to water stress in tomatoes and peppers. Plant Science, 166(2), 525-530. https://doi.org/10.1016/i.plantsci.2 $\underline{003.10 .025}$

Moore, J. E., Barton, M. D., Blair, I. S., Corcoran, D., Dooley, J. S., Fanning, S., Kempf, I., Lastovica, A. J., Lowery, C. J., Matsuda, M., McDowell, D. A., McMahon, A., Millar, B. C., Rao, J. R., Rooney, P. J., Seal, B. S., Snelling, W.
J., \& Tolba, O. (2006). The epidemiology of antibiotic resistance in Campylobacter. Microbes and infection, 8(7), 19551966.

https://doi.org/10.1016/i.micinf.20 $\underline{05.12 .030}$

Penrose, D. M., \& Glick, B. R. (2003). Methods for isolating and characterizing ACC deaminasecontaining plant growth-promoting rhizobacteria. Physiologia plantarum, 118(1), 10-15. https://doi.org/ 10.1034/j.13993054.2003.00086.x

Reed, M. L., \& Glick, B. R. (2005). Growth of canola (Brassica napus) in the presence of plant growth-promoting bacteria and either copper or polycyclic aromatic hydrocarbons. Canadian Journal of Microbiology, 51(12), 1061-1069. https://doi.org/10.1139/w05-094

Ryan, R. P., Germaine, K., Franks, A., Ryan, D. J., \& Dowling, D. N. (2008). Bacterial endophytes: recent developments and applications. FEMS microbiology letters, 278(1), 19. https://doi.org/10.1111/j.15746968.2007.00918.x

Taghavi, S., Van Der Lelie, D., Hoffman, A., Zhang, Y. B., Walla, M. D., Vangronsveld, J., Newman, L., \& Monchy, S. (2010). Genome sequence of the plant growth promoting endophytic bacterium Enterobacter sp. 638. PLoS genetics, 6(5),e1000943.

https://doi.org/10.1371/journal.pg $\underline{\text { en.1000943 }}$

Yao, M., Ose, T., Sugimoto, H., Horiuchi, A., Nakagawa, A., Wakatsuki, S., Yokoi, D., Murakami, T., Honma, M. \& 
Biotropic 2019. Vol.3(1): 13 - 23

Identification of 1-Aminocyclopropane-1-Carboxylic Acid (ACC)-Deaminase Producing Endophytic Bacteria from Local Agricultural Plantation Based on 16s Ribosomal RNA Gene As Genetic Marker

Tanaka, I. (2000). Crystal structure

of

carboxylate deaminase from

Hansenula saturnus. Journal of
Biological Chemistry, 275(44), 3455734565. https://doi.org/10.1074/jbc.M0046 81200 